\title{
The role of the community in supporting coral reef restoration in Pemuteran, Bali, Indonesia
}

\author{
Tyas Ismi Trialfhianty ${ }^{1} \cdot$ Suadi $^{2}$
}

Received: 25 February 2017 / Revised: 28 June 2017 / Accepted: 16 August 2017 / Published online: 26 August 2017

(C) The Author(s) 2017. This article is an open access publication

\begin{abstract}
Coral reef restoration projects have been conducted worldwide to increase the viability of damaged coral reef ecosystems. Most failed to show significant results. A few have succeeded and gained international recognition for their great benefits to ecosystem services. This study evaluated reef restoration projects in North-west Bali from the perspective of the local community over the past 16 years. As community participation is a critical support system for coral reef restoration projects, the contributing factors which led to high community participation and positive perceptions are examined. Social surveys and statistical analysis were used to understand the correlations between community perception and participation. The findings showed a positive correlation between community perception and participation. The level of community participation also depended on how their work relates to coral reef ecosystems. They supported this project in many ways, from project planning to the religious ceremonies which they believe are fundamental to achieve a successful project. Several Balinese leaders became 'the bridge' between global science and local awareness. Without their leadership, this study argues that the project might not have achieved the significant local support that has restored both the environment and the tourism sector in North-West Bali.
\end{abstract}

Tyas Ismi Trialfhianty

ttrialfhianty01@qub.ac.uk

Suadi

suadi@ugm.ac.id

1 School of Biological Sciences, Queen's University Belfast, Belfast, UK

2 Department of Fisheries, Universitas Gadjah Mada, Yogyakarta, Indonesia
Keywords Restoration project · Coral reef · Participation · Perception

\section{Introduction}

Worldwide decline of coral reef ecosystems has caused serious setbacks for the environment and humans, from loss of goods, services and functions such as fisheries habitat, shore protection, and tourism (Moberg and Folke 1999; Jones et al. 2004). Destruction of coral reef ecosystems has prompted increased coral reef restoration projects and study of their effectiveness (Rinkevich 2005). Many coral reef restoration and conservation projects have been established worldwide. However, a review of thirty reef conservation projects around the globe revealed that only half of them had achieved a significant benefit and success, whereas others showed none or only limited success (Baine 2001). Furthermore, the rate of decline of corals in Marine Protected Areas, even those that are actively managed, are no slower than in nearby areas that are not managed at all (Jones et al. 2004; Bruno and Valdivia 2016). These studies have risen questions of "what are the factors contributing to the effectiveness of reef restoration and conservation projects worldwide?'.

The factors contributing to success and failure, or weaknesses that may prevent many restoration projects from reaching their goals, have rarely been evaluated, but are usually blamed on lack of management by "paper parks" that have been officially designated but lack funding for effective enforcement, rather than failure of the managers to identify and control the real causes of coral mortality (Goreau and Hilbertz 2005). Increased development and construction in coastal areas, followed by lack of government support, are claimed to be the biggest factors in one project's failure (Luttinger 1997). 
Social factors such as education and the active participation of fisher and coastal communities were key reasons for success of some reef conservation projects (White and Vogt 2000). Many effective conservation projects and coral reef management concepts involved various community and user groups such as fishers, hotel owners, scuba divers and other coastal communities (Christie and White 1997), so it should be expected that the same is true for restoration as well as conservation.

In Pemuteran Bali, Indonesia, local fishermen interviewed in this study said that the decline of the coral reef ecosystem began around 1980. Human activity was the primary factor blamed for this decline, due to use of bombs and cyanide to catch the fish. At that time, Pemuteran was considered the poorest village in Bali and the majority of the people are uneducated (pers comm the Head of the Village Government, Jro Wirdika). The extremely dry local weather conditions made rice cultivation impossible and desperate economic conditions forced them to exploit coral reef fisheries for food. Awareness of the need to restore and protect their particular area of the sea increased slowly, and reef restoration projects were established in 2000 (Goreau 2009). Since then, the reef restoration projects have brought benefits to the community by increasing marine biodiversity and improving the environment for tourist through underwater attraction for diver and snorkelers (Jamison 2009). Our economic studies in 2016 reported that a five-fold increase in diving activities in the reef restoration site, amounted to US\$62,932 net benefit per year (manuscript in preparation). It is believed, they have created multiplier-effects through the tourism sector and increased economic development by providing jobs (pers comm local entrepreneur, Agung Prana). Furthermore, the data of Buleleng Regency (from 2010 to 2015) showed that the number of unemployed decreased gradually up to $85.31 \%$ within only 5 years. The growing tourism industry has been a great contributory factor to the decrease of unemployment numbers.

The projects use Biorock electric reef technology (Hilbertz and Goreau 1996), which allows coral to grow faster, survive in low-water-quality, heal faster and be more resistant to environmental stress such as pollution and high temperature (Goreau 2012). The major reef building coral Acropora nobilis grew four times faster with Biorock than controls (Jompa et al. 2012). This technology helped Pemuteran communities to restore their marine ecosystems and fisheries, and has become the inspiration for its tourism development, since it provides a beautiful landscape of underwater panoramas full of bright corals and fishes.

This study focused on the role of community support for a locally-managed coral reef restoration project in Bali that is regarded as one of the most successful, having received many international environmental and ecotourism awards including the United Nations Equator Award for Community-Based Development and the Special UN Development Programme
Award for Ocean and Coastal Management at the UN Conference on Sustainable Development in Rio de Janeiro, Brazil, in 2012 (UNDP 2012). The project in Pemuteran is considered as a restoration project. However, both conservation and restoration projects in the community often translate as one meaning, that is hard to be distinguished one to another.

Ostrom (1999), emphasised identification and analysis of the factors for the emergence of collective action. This paper evaluated social driving factors supporting coral reef restoration in Pemuteran. The impacts of the project will be examined by looking at the community's perceptions of them. We evaluated the major driving forces boosting social awareness and increasing participation leading to the success of the project. Other coral reef restoration and conservation projects can use this example to improve their future project planning.

\section{Materials and methods}

\section{Site description}

Reef rehabilitation projects are in Banjar Loka Segara, in North-West Pemuteran (see Fig. 1). They are in four main areas (all within the red dot on the map below). The first area is the largest, covering 1.5 ha and managed by the Karang Lestari Foundation. The second and third areas are managed by Reef Seen Diving Centre. The fourth area is managed by Adi Asri Resort. Social-demographic data published by the Bali Regional Government (2014), show that Pemuteran had 4.747 people, with various occupations dominated by farming, fishing, tending cattle, entrepreneurs, and civil servants.

\section{Data collection}

This study was carried out between April to May 2016, using in-depth interviews and surveys. Surveys were conducted by face-to-face interviews by a local interviewer. Interviewers had been trained before and had on-going contact with the researcher about any problems and misunderstanding that might have arisen in the interview. The in-depth interview was conducted in the office where they worked. There are eight sections in the survey which consist of; (1) basic information (e.g. age, occupation, education, income), (2) knowledge about the coral reef and its benefits, (3) knowledge about the reef rehabilitation project, (4) their sources of information or knowledge, (5) perception of the project's benefit and impact, (6) satisfaction with the project's achievement, (7) participation in the project's activities, and (8) willingness to support the project. 


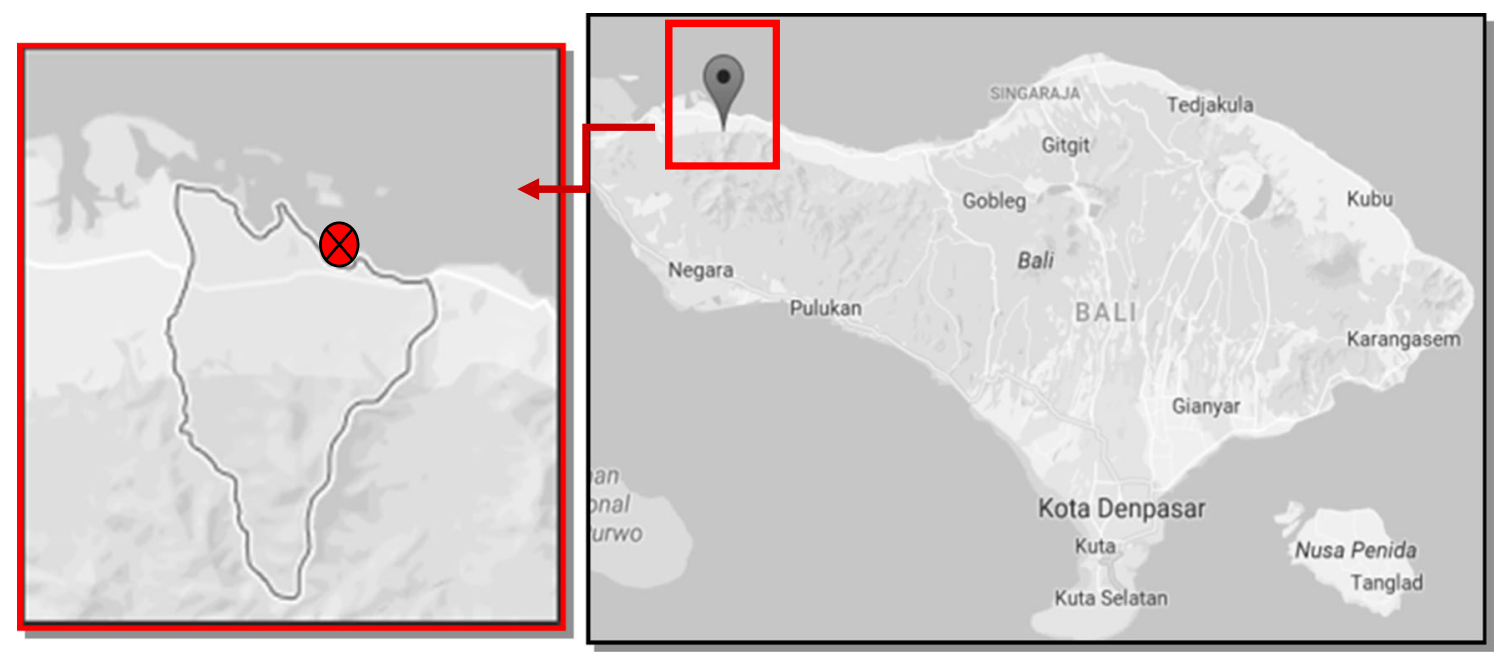

Fig. 1 Study location in Pemuteran village, North-west Bali

\section{Population sample selection}

Decisions on which local populations to interview (sample selection) were made in consultation with the Karang Lestari Foundation and the traditional local village government (Desa Pemuteran). The groups interviewed were divided into communities whose activities were near the sea and those which were far from the sea (later we use the term 'level of interaction'). A high level indicated that the community spent more time near the sea and near the projects. A low level indicates less interaction, such as farmers living inland. Analysis of these relationships helped understand the impact on and participation by the community in the project and explained how their work and residence locations influenced their perceptions of it. We also included tourists in the survey to learn more about their role in this project, given the fact that tourists are a key factor contributing to the growing economic development in Pemuteran (pers comm the Head of the Village Government, Jro Wirdika). They were surveyed near the shore.

The Snowball Sampling Method was used, which allows the researcher to go deeper and find more accurate information from selected respondents (Quinn 2002). In this study we asked key informants, 'Who knows a lot about the project but has a different profile (the detail type of occupation) than you?' (e.g. asking a diving instructor to recommend a person who works in a different diving centre). Although the sample size was small it included a great diversity of respondents with regard to living places, work places, income level, occupation, age, and education. We used local people as interviewers since they knew the place and the community best. We conducted in-depth interviews with local and traditional (customary) village government, the founders of the project, the projects' teams and the chairman of each community.

\section{Community background}

Fishers Twenty fishers were interviewed in this study. In the late 1980s, fishing was the main economic activity in the coastal area of Pemuteran. However the growing tourism industry on the beach and traditional rules limited the fishing area. Also the economic activities of the fishers shifted towards tourism activities such as becoming tour guides, diving instructors, dive centre officers, or working in hotels. This resulted in a decline in full-time fishers.

Pecalang Laut (sea police) Traditional village marine police protect the marine area from illegal and destructive fishing (using bombs and cyanide). We interviewed 10 Pecalang Laut in this study.

Diving centre and diving instructors The tourism sector including water recreation, such as diving and snorkelling, were beneficiaries of increased coral reef tourism activity in Pemuteran. Eleven people working in diving centres (mostly local diving instructors) were interviewed to understand the projects' impacts and achievements over the past 6 years.

\section{Tourism sector (resort/hotel officer and entrepreneur)} Growing reefs providing beautiful underwater panoramas have attracted tourists from all over the world to Pemuteran. Most tourists knew about the restoration projects before they came and stated it was a factor in their coming, almost all knew about the project when they left (Jamison 2009). Since the projects are not marketed, publicity about the projects has largely seen by word of mouth, visitors tell their family friends, and come back repeatedly to see the changes. This provides a multiplier effect for other tourism sectors such as hotels, restaurants, and tourist guide centres. Twenty people who worked in the tourism sector were interviewed, for understanding how the project benefits tourism in Pemuteran. 
Farmers Most people in Pemuteran are farmers, relying on agro-business profits. Farmers are our 'far-from-the sea' community. They give us the perspective on how well the projects information is spread throughout Pemuteran. Ten farmers were interviewed in this study.

Tourists As it is a major tourist area, we interviewed 38 tourists near the project areas.

\section{Data analysis}

This study combined qualitative and quantitative methods because the advantage of using both approaches is to reduce the weaknesses of a single method and complement each other (Meinzen-Dick et al. 2004). The quantitative method included multivariate statistical analysis and sample surveys, and the qualitative method used in this study included an in-depth interviews and participant observations, as suggested by (Cook and Reichardt 1979). Such understanding requires monitoring, impact assessment and causal explanation (Cook and Reichardt 1979).

\section{Results}

\section{Sample characteristics}

The total number of respondents was 116 people. This included the key informants $(n=7)$ who were given both structured and unstructured questions to support and complete the information from the surveys. The respondents had various demographic characteristics (see Table 1). Most of them were of working age, between 18 and 50 years old.

\section{Perception of reef rehabilitation project}

The survey showed that $86.7 \%$ of respondents agreed that Pemuteran reefs were damaged before the project was established. We compared two perception variables, opinion on the benefit of the coral reef to humans, and the need to restore it. We can see a relationship between people who recognised the benefits of the reef and then felt the need for restoration.

Individual awareness of the need to protect the reef (Fig. 2) showed that people who agree that reefs bring positive impacts for humans firmly believed that reefs should be restored (see blue sector, amounted to 104 people). On the other hand, people who question whether the reef has a positive benefit on humans gave a neutral response (green sector, amounted to 3 people). Whereas, the others (grey sector, amounted to 4 people) do not know about the reef.

More than half of all respondents strongly agreed that the reef rehabilitation projects have provided benefits for the community and no one disagrees with this statement (see Table 2). However, knowledge levels about the project were considered intermediate. Chi-square cross tabulation analysis between the two perceptions below (dependent variable) and type of communities (independent variable) showed that there was a significant difference between the response given by each community $(p<0.05)$. Furthermore, it explained how demographic characteristics of each community and their level of interaction with the project affected their perception of it.

We looked further into the personal benefit they felt from the project. The greater number of respondents (38.9\% of the total sample, Fig. 3) believed that the reef rehabilitation project using Biorock technology had given them a beautiful underwater panorama. The second biggest benefit which $36.5 \%$ of the population admitted was that the project gave them income from tourism.

Each community in Pemuteran has different major occupations. We hypothesised that communites living close to the sea having direct interactions with the project will have a good knowledge of and perspective on the project goals. The level of interaction is divided by three criteria; high, intermediate and low interaction. This hypothesis was tested using Spearman correlation analysis. In Table 3 below, there are six perceptions about the project that we tested. The correlation coefficients between $\mathrm{Y}$ or the dependent variable (the perception) and $\mathrm{X}$ or independent variable (level of interaction) showed different coefficient values. There are three $\mathrm{Y}$ variables which indicated a significant negative relationship at the 0.01 level to community level interaction ( $\mathrm{X}$ variables) such as the knowledge of the project, knowledge of the reef ecosystem, and satisfaction with the project. It explained why the level of interaction did negatively correlate with the three perceptions mentioned above. Communities geographically far from the project such as tourists may have a better knowledge of the project and have a high level of interaction than communities that are closer, such as local farmers.

The survey on the information dissemination about the project showed that the greatest contributing factor that led to the spread of knowledge about the project was friends and colleagues (about $27.8 \%$ as opposed to $18.5 \% ; 15.7 \% ; 7.4 \%$ and $6.5 \%$ from the other source of information such as project information campaigns, government, website and magazine, respectively). For instance, some tourists from Europe may possess better knowledge about the project from family, friends, and dive magazines than a farmer who lives in the hills above Pemuteran, because their friends who knew about the project helped to spread the information. However, the perception of the need to protect the reefs in Pemuteran showed a positive correlation. Thus, the result assumed that the closer a community is to the sea or the project's area, the more they believe that the reefs should be protected Figs. 4 and 5 . 
Table 1 The character of respondents based on their communities

\begin{tabular}{|c|c|c|c|c|c|c|}
\hline & Fisher & $\begin{array}{l}\text { Dive } \\
\text { Instructor }\end{array}$ & $\begin{array}{l}\text { Pecalang } \\
\text { Laut }\end{array}$ & $\begin{array}{l}\text { Tourism (entrepreneur/ } \\
\text { labor) }\end{array}$ & Farmer & Tourist \\
\hline \multicolumn{7}{|l|}{ Gender } \\
\hline Male & 20 & 11 & 10 & 16 & 9 & 19 \\
\hline Female & 0 & 0 & 0 & 11 & 1 & 19 \\
\hline \multicolumn{7}{|l|}{ Age } \\
\hline 18-30 & 3 & 8 & 2 & 10 & 6 & 9 \\
\hline $31-45$ & 15 & 3 & 8 & 10 & 3 & 11 \\
\hline $46-59$ & 1 & 0 & 0 & 3 & 1 & 15 \\
\hline$>60$ & 1 & 0 & 0 & 4 & 0 & 3 \\
\hline \multicolumn{7}{|l|}{ Education } \\
\hline $\begin{array}{l}\text { Elementary } \\
\text { school }\end{array}$ & 5 & 0 & 3 & 1 & 3 & 0 \\
\hline $\begin{array}{l}\text { Secondary } \\
\text { school }\end{array}$ & 9 & 4 & 5 & 4 & 2 & 0 \\
\hline Tertiary school & 5 & 7 & 2 & 14 & 4 & 2 \\
\hline \multirow{2}{*}{\multicolumn{7}{|c|}{$\begin{array}{l}\text { Diploma/Univer- } \\
\text { sity } \\
\text { Income* (per month) }\end{array}$}} \\
\hline & & & & & & \\
\hline Low & 6 & 0 & 2 & 1 & 8 & 0 \\
\hline Middle & 14 & 11 & 8 & 21 & 2 & 6 \\
\hline High & 0 & 0 & 0 & 5 & 0 & 32 \\
\hline
\end{tabular}

*Low income $=<$ USD50; Middle income $=$ USD51-550; High income $=>$ USD551

\section{Participation}

The data showed that about $56 \%$ of the community participated in the project. Many feel they have been involved in various parts of the project work (see Fig. 6 for details of their involvement). Looking closely at the percentage of the community's participation, three major communities had the

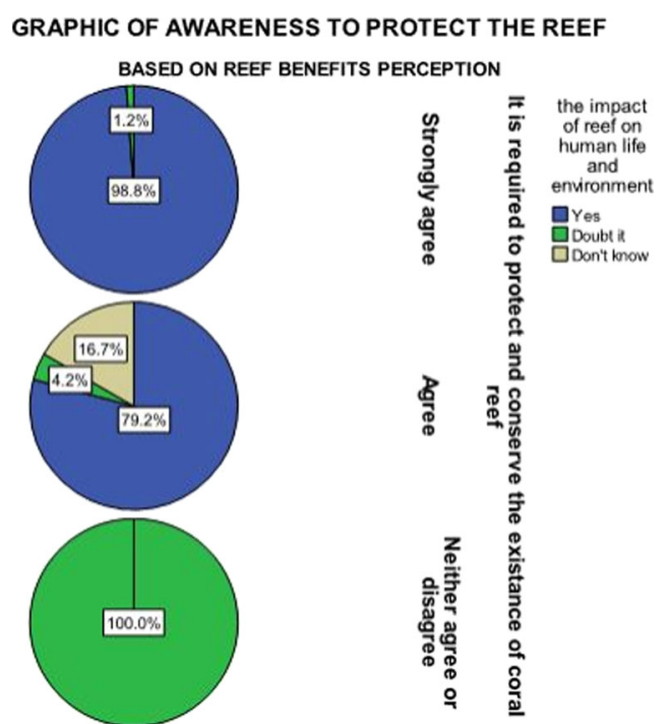

Fig. 2 Perception between the positive impact of reefs and the need to protect it highest percentage of involvement among all. They are Pecalang Laut, dive instructors, and fishers. These communities have a significant interaction with the project because most of their work is at sea.

The highest type of participation of the community is in the periodic Biorock Reef Restoration Training Workshops, amounting to $21.3 \%$ of the total (see Fig. 6). Around once a year, the Karang Lestari Foundation organised training workshops for students, scientists, and other interested groups around Indonesia. These workshops are a key part of the project's campaign and learning dissemination, which the organisers believe needs to be spread to communities across Indonesia, to help them also restore their coral reef ecosystems and fisheries. The collection of naturally broken coral fragments is the second highest type of participation, about $20.5 \%$. Diving instructors whose participation is $100 \%$ within their community are considered as the greatest contributing factor to this type of participation. Interestingly, our survey revealed that the making of the Biorock structure, the third highest type of the community's participation, has involved low-level interaction of the farming community. They declared that they have participated by doing spiritual ceremonies conducted at the beach and village Temples in preparation for the Biorock structure before its installation on the bottom of the seabed.

Spearman correlation analysis (see Table 4) shows that there are two $\mathrm{X}$ (independent) variables within the perceptions that have a significant negative relationship to community 
Table 2 Perceptions of public knowledge about the project and its benefits

\begin{tabular}{|c|c|c|c|c|c|c|c|c|}
\hline & Fisher & $\begin{array}{l}\text { Dive } \\
\text { instructor }\end{array}$ & Farmer & Tourist & $\begin{array}{l}\text { Tourism } \\
\text { sector }\end{array}$ & $\begin{array}{l}\text { Pecalang } \\
\text { Laut }\end{array}$ & $\begin{array}{l}\text { Total } \\
(\%)\end{array}$ & $\begin{array}{l}\text { Chi- } \\
\text { square } \\
\text { test }\end{array}$ \\
\hline \multicolumn{9}{|c|}{ The project benefits } \\
\hline $\begin{array}{l}\text { Strongly } \\
\text { agree }\end{array}$ & 17 & 7 & 6 & 14 & 10 & 10 & 58.7 & \multirow[t]{4}{*}{0.003} \\
\hline Agree & 3 & 4 & 3 & 17 & 12 & 0 & 35.7 & \\
\hline $\begin{array}{l}\text { Neither } \\
\text { agrees/- } \\
\text { disagree }\end{array}$ & 0 & 0 & 1 & 5 & 0 & 0 & 5.6 & \\
\hline Disagree & 0 & 0 & 0 & 0 & 0 & 0 & 0 & \\
\hline \multicolumn{9}{|c|}{ How good is your knowledge about the project } \\
\hline Very good & 3 & 0 & 4 & 2 & 1 & 0 & 9.1 & \multirow[t]{5}{*}{0.000} \\
\hline Good & 6 & 2 & 3 & 15 & 2 & 0 & 25.2 & \\
\hline Quite good & 0 & 2 & 0 & 4 & 6 & 2 & 12.6 & \\
\hline Not that good & 6 & 4 & 2 & 14 & 11 & 1 & 34.2 & \\
\hline $\mathrm{Bad}$ & 5 & 3 & 1 & 3 & 2 & 7 & 18.9 & \\
\hline
\end{tabular}

participation (Y or dependent variables). It explains why knowledge of the project and willingness to get involved in the future do not depend on community participation. A community with a poor understanding of the project is more willing to participate in the future. They have this in common with a community with a low level of participation, which is also more willing to become involved in the project. In contrast, both levels of interaction and personal benefit show a significant positive relationship with participation. The more people interact with the sea/project's location, the more they participate. Moreover, the more they feel personal benefits from the project, the more they are motivated to help with the project. A previous social study in Bali by Suadi and Nakagawa (2009), also found that the higher the benefit of the project, the more prominent is the community participation and support for the project goals.

Regression analysis between the Y or dependent variable (community participation) and two $\mathrm{X}$ or independent variables (perceptions and level of interaction) showed that the Rsquare value describes $26.1 \%$ of the variation $\left(\mathrm{R}^{2}=0.261\right)$ within community participation as influenced by perceptions and level of interaction (see Table 5). ANOVA tests show

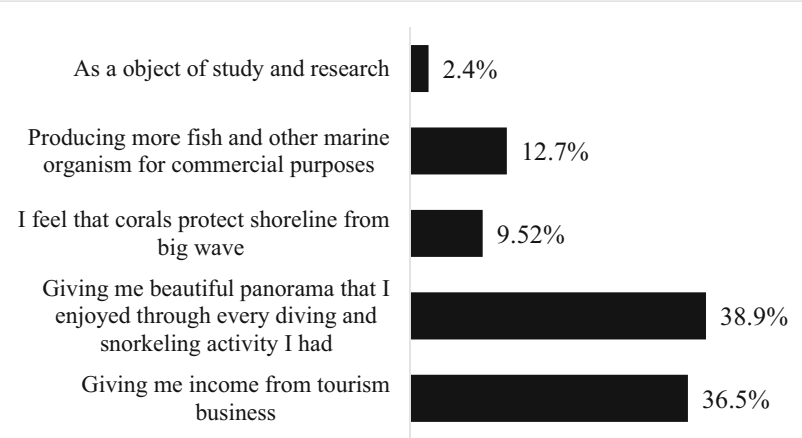

Fig. 3 The personal benefit of reef rehabilitation project $p<0.05$, which supported the idea that this regression model can predict variation in community participation. Furthermore, the regression coefficient $p<0.05$ explained that the two independent variables are significant in predicting the change of the community's participation in the future.

Additionally, looking at the economic background of respondents, both variables; perception (the positive perception on restoration project's benefit and impact to the reef) and participation showed a significant correlation at the level 0.05 and 0.01 for perception and participation, respectively (data not shown) .

\section{The bridge}

We interviewed key informants who knew in Pemuteran before the project was established (more than 16 years) using structured and unstructured questions. All respondents said that a key element supporting project success is 'masyarakat'

Table 3 Spearman correlation between community's level interaction and perception

\begin{tabular}{lc}
\hline Perceptions & $\begin{array}{c}\text { Correlation } \\
\text { coefficient }\end{array}$ \\
\hline $\begin{array}{l}\text { How good your knowledge is about the reef } \\
\text { rehabilitation project }\end{array}$ & $-0.285^{* *}$ \\
$\begin{array}{l}\text { Reef restoration project had helped to restore } \\
\text { coral reef from damage. In the present, the } \\
\text { condition of reef is significantly improved }\end{array}$ & 0.335 \\
$\begin{array}{l}\text { It is required to protect and conserve the existence } \\
\text { of coral reef in Pemuteran }\end{array}$ & 0.124 \\
$\begin{array}{l}\text { It is possible to restore the damage of coral reef } \\
\text { The good condition of reef had positive relation } \\
\quad \text { with the abundant of fish and marine organism }\end{array}$ & $0.424^{* *}$ \\
The satisfaction of reef rehabilitation project & $-0.246^{* *}$ \\
\hline
\end{tabular}

**Correlation is significant at the 0.01 level (2-tailed) 
Fig. 4 The percentage of community's participation

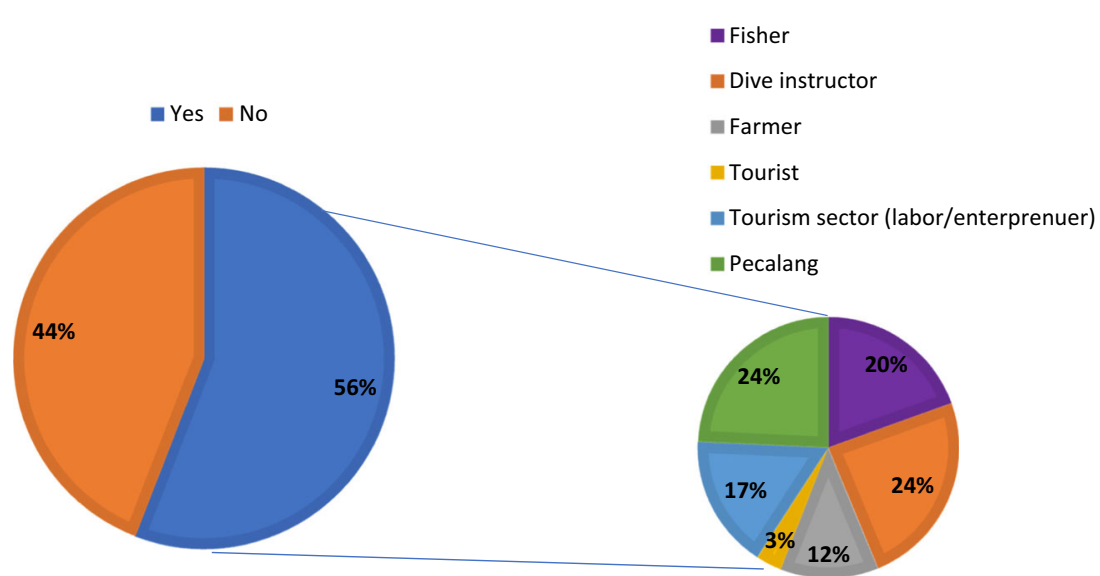

or 'community'. This word describes a group of people who stay in Pemuteran for short or long periods of time, have different occupational backgrounds, and mostly spend their time in the coastal area. Some of them are not locals, but immigrants from other parts of Bali, Indonesia, or abroad who want to help Pemuteran restore their coral reef ecosystem.

Knowing that positive perception and participation was high, we sought further information to address the questions below:

- Who is responsible for building awareness among locals?

- Who makes local fishers want to stop fishing in the reef conservation area and also stops those who are using bombs and cyanide to fish?

- Who makes coastal communities want to support the project voluntarily and financially?

We concluded that crucial support for this project is from a group of local Balinese people whom we called 'the bridge'. They are the answer to each of the above questions. 'The bridge' translates the global scientific language about the need to protect reef ecosystems into the local language. These individuals had gained the trust and attention of the community

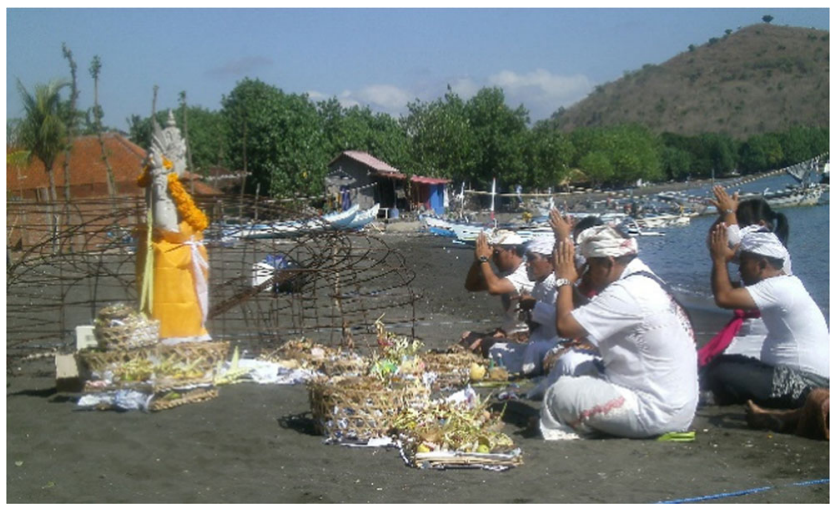

Fig. 5 Spiritual ceremony at the Biorock steel structure before its installation. Doc: the Karang Lestari Foundation more than government and NGOs. A personal approach is a way to enter the community's trust. Firstly, they used spiritual beliefs (the Holy Spirit that influences Balinese lives) as one of the tools. The individual who can translate and actualize local beliefs and philosophy, the Tri Hita Karana (three primary causes of goodness), is likely to gain much more trust than others. The Tri Hita Karana creed emphasises the balanced and harmonious relationship between man, the environment, and the creator (pawongan/human, palemahan/environment, and parahyangan/God). They increased expectations of a higher standard of living (Pemuteran was considered as the poorest village at that time) by giving hope with the idea that restoring and conserving natural resources is the best investment for the future.

\section{Discussion}

This study found that community support reef restoration was due to benefits and positive impact from it, and strongly affected by participation and knowledge about it. The analysis clearly showed that the demographic background (especially income) and the level of interaction may affect the community's perspective. The difference between community perspectives and attitudes is mainly related to their socioeconomic demographic variables (Gelcich et al. 2005). The level of interaction is the intensity of community involvement in the project. This study showed that high level of interactions affect the way people think about whether reef ecosystems should be restored or not. However when the level of interaction is related to the level of dependency, it may have negative relationships towards people's attitudes to the reef ecosystems because the more their livelihood depends on it, the more they are likely to exploit it (Marshall et al. 2010) a sort of "use it until you lose it" or "familiarity breeds contempt" attitude.

Many other studies have tried to understand the factors that most affect community perspectives of 
Fig. 6 The type of community's participation

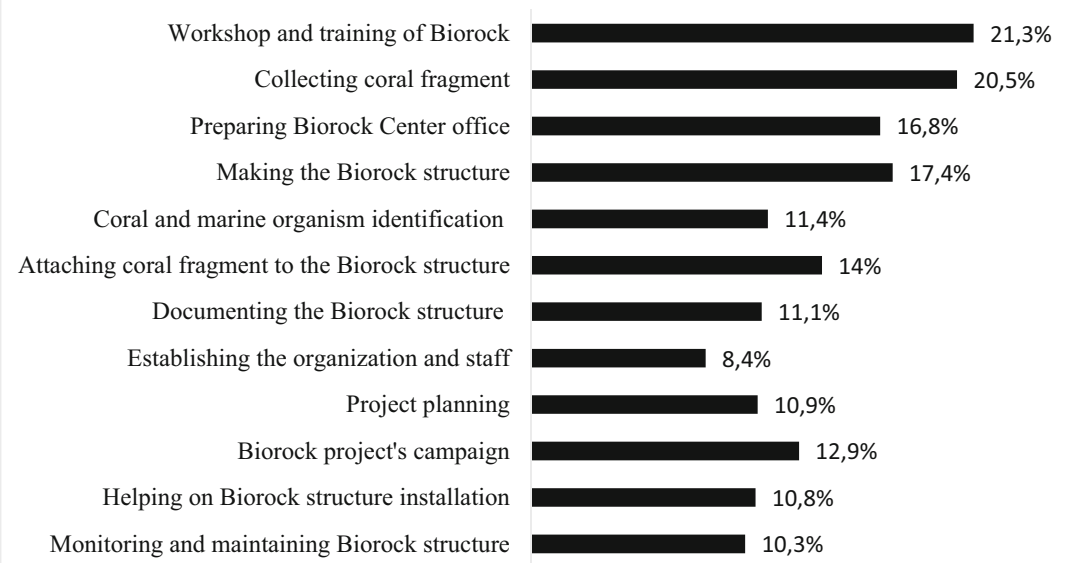

conservation projects. A study of a Marine Protected Area (MPA) in Tanzania found that the success of the project mostly depended on the community and fishers' type of equipment (Kincaid et al. 2014). Others demonstrated that culture and the need to support lives could be a greater influence on community perspectives of marine resources. As these two factors caused significantly distinct perceptions between divers and fishers (Sandersen and Koester 2000). With many possible factors affecting the community perspectives, we find one particular problem in this study; neither the demographic background nor the level of interaction can be changed because occupation is the factor affecting them the most. Therefore, future management strategies should think how to build positive perceptions and awareness to support the project goals, as a supportive community attitude towards the project is always essential for restoration and conservation projects (Alexander 2000; Ormsby and Kaplin 2005; Allendorf et al. 2006; Vodouhê et al. 2010). Furthermore, education is a crucial platform for changing community perspectives into support for the project (White and Vogt 2000; Fadli et al. 2012). Education is also necessary to

Table 4 Spearman correlation between community's participation and perception

\begin{tabular}{ll}
\hline Participation & Correlation coefficient \\
\hline $\begin{array}{l}\text { How good is your knowledge is about } \\
\text { the reef restoration project }\end{array}$ & $-0.357^{* *}$ \\
Level of interaction & $0.466^{* *}$ \\
It is required to protect and conserve the & -0.006 \\
$\quad$ existence of coral reef & $0.238^{*}$ \\
Personal benefit from the project & $-0.416^{* *}$ \\
Willingness to get involved & -0.178 \\
The satisfaction of the project & \\
\hline
\end{tabular}

*Correlation is significant at the 0.05 level (2-tailed)

***Correlation is significant at the 0.01 level (2-tailed) assist environmentally-based enterprises to help attain the project's goals (Salafsky 1999).

Another contributory factor supporting the coral reef restoration project is community behaviour towards the environment such as; (1) whether a community wants to participate in the project, (2) willingness to become involved and, (3) which roles they might be able to join in for creating a better marine ecosystem in the future. This study shows that the level of interaction and personal benefit are associated with the community's participation. It makes sense because people feel the more they get benefit from resources the more they are willing to protect and restore it. Others studies showed that support from the community occurred after they felt an increase in food supply, from which they could take benefit (e.g. the increase of fish catches) (Benbow and Harris 2011).

Community behaviour may be influenced by environmental concerns, knowledge and attitudes (Olli et al. 2001). However this study found that the knowledge of the community did not correlate with its participation. It is not so much that the more people know about the project, the more positive they will feel, but rather the more they recognise that the project has given them benefit the more committed to it they become. In addition, an individual sense of responsibility also influences community behaviour (Hines et al. 1987). Improving education and building awareness to increase a sense of responsibility within communities will be valuable in the future.

The coral reef restoration project in Pemuteran has given benefits to communities by providing a beautiful underwater panorama for tourism and fisheries purposes. Ecotourism offers the best available local opportunity to increase the community's economic standard of living (Stem et al. 2003a). This will improve people's perception of their personal benefits and lead them to restore and conserve marine ecosystems. Moreover, ecotourism can 
Table 5 Regression analysis between community's participation and perception

\begin{tabular}{|c|c|c|c|c|c|c|}
\hline & $b$ & $S E b$ & $\beta$ & R-Square & $\begin{array}{l}\text { Regression } \\
\text { coefficient }\end{array}$ & ANOVA test \\
\hline Constant & 1.447 & 0.278 & & \multirow[t]{5}{*}{0.261} & \multirow[t]{5}{*}{0.000} & \multirow[t]{5}{*}{0.000} \\
\hline It is required to protect and conserve the existance of coral reef & -0.181 & 0.101 & -0.161 & & & \\
\hline How good your knowledge is about the existence of the project & -0.104 & 0.039 & -0.268 & & & \\
\hline Do you personally feel the benefit of the project & 0.060 & 0.114 & 0.053 & & & \\
\hline Level interaction & 0.285 & 0.072 & 0.354 & & & \\
\hline
\end{tabular}

be used as an incentive to support the projects (Bushell and Eagles 2006).

For sustainability purposes it is essential to understand the motives behind the community participation and support for the project. Where the community is more likely to invest their revenue in the tourism sector solely to improve their wellbeing, rather than being concerned for the marine ecosystem (Stem et al. 2003b), it will be a threat to the sustainability of the project which relies on the support of ecotourism.

This study focused on understanding why the community's positive perception and participation are high. We found 'the bridge' as the vital element by which these two variables improved significantly over the years. Positive perceptions built by a personal approach, using an essential local beliefs (in this case, Balinese Hindu beliefs which encourage their follower to protect nature because God's soul is at rest within nature). This positive perception leads to a high level of community participation to support the project. Where lack of participation was not associated with lack of interest, because people simply need money and food to survive (Méndez-López et al. 2014), jobs were found for them in the tourism sector. As a result of expanding economic opportunities and jobs in tourism, the number full-time local fishers in Pemuteran has declined.

\section{Conclusions}

The successful environmental and economic results of the coral reef conservation projects in Pemuteran, North-west Bali, are results of a high level of positive perception and participation by the community. These two variables are strongly correlated with demographic background, the level of the community's interaction and the personal benefit they felt from the project. 'The Bridge' is the greatest contributory factor supporting a gradual increase of both variables. They build perception by using the vital beliefs of the locals and providing jobs in the tourism sector to prevent fishers using bombs and cyanide to fish. For the sustainability of the marine ecosystem and the project, we suggest that every coastal community should clarify their priorities and goals in the tourism industry, and put restoring the health and sustainability of the marine ecosystem at the top of their goals alongside their other objectives.

Acknowledgements This paper is funded by Indonesia Endowment Fund for Education Scholarship (LPDP). Our gratitude to Dr. Thomas J. Goreau, Agung Prana, Agung Bagus Mantra, Agung Kertiyasa, P. Tasya Karissa, Komang Astika and Setyadi with their wonderful support and their valuable opinon. We thank the Head of Village Government and Head of Regional Government for legal permission of this study.

Open Access This article is distributed under the terms of the Creative Commons Attribution 4.0 International License (http:// creativecommons.org/licenses/by/4.0/), which permits unrestricted use, distribution, and reproduction in any medium, provided you give appropriate credit to the original author(s) and the source, provide a link to the Creative Commons license, and indicate if changes were made.

\section{References}

Alexander SE (2000) Resident attitudes towards conservation and black howler monkeys in Belize: the community baboon sanctuary. Environ Conserv 27(04):341-350

Allendorf T, Swe KK, Oo T, Htut Y, Aung M, Allendorf K, Hayek L, Leimgruber P, Wemmer C (2006) Community attitudes toward three protected areas in upper Myanmar (Burma). Environ Conserv 33(04):344-352

Baine M (2001) Artificial reefs: a review of their design, application, management and performance. Ocean Coast Manag 44(3):241-259

Benbow S, Harris A (2011) Managing Madagascar's octopus fisheries. Proceedings of the workshop on Octopus Cyanea fisheries 2011, pp 5-6

Bruno JF, Valdivia A (2016) Coral reef degradation is not correlated with local human population density. Sci Rep 6:29778

Bushell R, Eagles PF (2006) Tourism and protected areas: benefits beyond boundaries: the Vth IUCN world parks congress. CABI, Cambridge

Christie P, White AT (1997) Trends in development of coastal area management in tropical countries: from central to community orientation. Coast Manag 25(2):155-181

Cook TD, Reichardt CS (1979) Qualitative and quantitative methods in evaluation research. Sage publications, Beverly Hills

Fadli N, Campbell SJ, Ferguson K, Keyse J, Rudi E, Riedel A, Baird AH (2012) The role of habitat creation in coral reef conservation: a case study from Aceh, Indonesia. Oryx 46(04):501-507

Gelcich S, Edwards-Jones G, Kaiser MJ (2005) Importance of attitudinal differences among artisanal fishers toward co- management and conservation of marine resources. Conserv Biol 19(3):865-875 
Goreau TJ (2009) Tourism and sustainable coral reefs, GCRA White Paper, 18pp. http://www.globalcoral.org/wp-content/uploads/2014/ 01/Ecotourism_Biorock_complete.pdf

Goreau TJ (2012) Marine ecosystem electrotherapy: practice and theory. In: Goreau TJ, Trench RK (eds) Innovative Methods of Marine Ecosystem Restoration. CRC Press, Boca Raton, pp 263-290

Goreau TJ, Hilbertz W (2005) Marine ecosystem restoration: costs and benefits for coral reefs. World Resour Rev 17(3):375-409

Hilbertz WH and Goreau TJ (1996) Method of enhancing the growth of aquatic organisms, and structures created thereby. U.S. Patent 5,543, 034

Hines JM, Hungerford HR, Tomera AN (1987) Analysis and synthesis of research on responsible environmental behavior: a meta-analysis. J Environ Educ 18(2):1-8

Jamison N (2009) The role of biorock artificial coral reefs in the sustainable governance of marine protected areas: a case study of Pemuteran, Bali, 60 p., M.Sc Thesis, Sustainability and Management Programme, Department of Geography, Royal Holloway College, University of London

Jompa J, Suharto EMA, Dwjja PN, Radiman U, Triyono H, Sue RA, Soeyasa N (2012) Electrically stimulated corals in Indonesia reef restoration projects show greatly accelerated growth rates. Pages 47-58 in T.J. Goreau and R.K. Trench, editor. Innovative Methods of Marine Ecosystem Restoration. CRC Press, Boca Raton

Jones GP, Mccormick MI, Srinivasan M, Eagle JV (2004) Coral decline threatens fish biodiversity in marine reserves. Proc Natl Acad Sci U S A 101(21):8251-8253

Kincaid KB, Rose G, Mahudi H (2014) Fishers' perception of a multipleuse marine protected area: why communities and gear users differ at Mafia Island, Tanzania. Mar Policy 43:226-235

Luttinger N (1997) Community-based coral reef conservation in the Bay Islands of Honduras. Ocean Coast Manag 36(1):11-22

Marshall NA, Marshall PA, Abdulla A, Rouphael T (2010) The links between resource dependency and attitude of commercial fishers to coral reef conservation in the Red Sea. Ambio 39(4):305-313

Meinzen-Dick R, Digregorio M, Mccarthy N (2004) Methods for studying collective action in rural development. Agric Syst 82(3):197-214

Méndez-López ME, García-Frapolli E, Pritchard DJ, González MCS, Ruiz-Mallén I, Porter-Bolland L, Reyes-Garcia V (2014) Local participation in biodiversity conservation initiatives: a comparative analysis of different models in south East Mexico. J Environ Manag 145:321-329
Moberg F, Folke C (1999) Ecological goods and services of coral reef ecosystems. Ecol Econ 29(2):215-233

Olli E, Grendstad G, Wollebaek D (2001) Correlates of environmental behaviors bringing back social context. Environ Behav 33(2):181-208

Ormsby A, Kaplin BA (2005) A framework for understanding community resident perceptions of Masoala National Park, Madagascar. Environ Conserv 32(02):156-164

Ostrom E (1999) Institutional rational choice: an assessment of the institutional analysis and development framework. Pages 35-71 in P. Sabatier, editor. Theories of the policy process. Westview Press, Boulder, Colorado

Quinn PM (2002) Qualitative research and evaluation methods. Sage Publications Inc, California EU

Rinkevich B (2005) Conservation of coral reefs through active restoration measures: recent approaches and last decade progress. Environ Sci Technol 39(12):4333-4342

Salafsky N (1999) Evaluating linkages between business, the environment, and local communities: final analytical results from the biodiversity conservation network. Biodiversity Support Program, Washington

Sandersen HT, Koester S (2000) Co-management of tropical coastal zones: the case of the Soufriere marine management area, St. Lucia, WI. Coast Manag 28(1):87-97

Stem CJ, Lassoie JP, Lee DR, Deshler DD, Schelhas JW (2003a) Community participation in ecotourism benefits: the link to conservation practices and perspectives. Soc Nat Resour 16(5):387-413

Stem CJ, Lassoie JP, Lee DR, Deshler DJ (2003b) How'eco'is ecotourism? A comparative case study of ecotourism in Costa Rica. J Sustain Tour 11(4):322-347

Suadi, Nakagawa M (2009) Sharing the commons: resolving the tragedy of the commons through collaborative Management of Coastal Commons at Kedonganan Village, Bali. J Kyosei Stud 3(1):263285

United Nations Development Programme (UNDP) (2012) The equator award for community based development, Rio de Janeiro, Brazil. http://www.globalcoral.org/wp-content/uploads/2014/01/karang _ lestari_equator_award.pdf

Vodouhê FG, Coulibaly O, Adégbidi A, Sinsin B (2010) Community perception of biodiversity conservation within protected areas in Benin. Forest Policy Econ 12(7):505-512

White AT, Vogt HP (2000) Philippine coral reefs under threat: lessons learned after 25 years of community-based reef conservation. Mar Pollut Bull 40(6):537-550 